Vol 1. No 2. Oktober Tahun 2021 e-ISSN : 2798-5466 P-ISSN : 2798-5725

\title{
IMPLEMENTASI APLIKASI EDM DAN E-RKAM DENGAN MENGGUNAKAN APLIKASI G-SUITE FOR EDUCATION PADA MADRASAH SASARAN PROYEK REALIZING EDUCATION'S PROMISE-MADRASAH EDUCATION QUALITY REFORM (REP-MEQR) IBRD LOAN NUMBER: 8992-ID TH.2020-2024
}

\author{
NUR SA'IDU \\ Pengawas Madrasah Kementerian Agama Kabupaten Semarang \\ e-mail: nuripurbosari68@gmail.com
}

\begin{abstract}
ABSTRAK
Kegiatan Bimtek EDM dan e-RKAM merupakan kegiatan pelatihan bagi madrasah sasaran penerapan EDM dan e-RKAM yang merupakan perubahan pengelolaan sistem BOS secara online bagian dari Proyek Realizing Education's Promise-Madrasah Education Quality Reform (REP-MEQR) IBRD Loan Number: 8992-ID tahun 2020-2024. Peran Tim Inti Kabupaten (TIK) sebagai pembimbing dalam pembimbingan Tim Inti Madrasah (TIM) sangat mendukung dalam menggali potensi yang dimiliki peserta Bimtek EDM dan e-RKAM melalui pelatihan peserta dengan memanfaatkan aplikasi LMS (Learning Manajemen System) berupa G-Suite for Education, sehingga setiap peserta TIM terampil menggunakan dalam memanfaatkan, menerapakannya dalam aplikasi EDM dan aplikasi e-RKAM.. Tahapan materi pelaksanaan dengan mengunakan sistem blended atau hybrid yang menggabungkan sistem syncronus asyncronus. Kerangka Kegiatan Bimtek dengan mengadaptasikan keunggulan $G$ Suite for Educationdengan (Virtual Classroom) sycnronus asyncronus. Fokus yang dituju adalah ketercapaian kemampuan dan ketrampilan peserta bimtek dengan berbagai strategi yang ada dilapangan lebih ditekankan pada tujuan keberhasilan bimtek agar madrasah mampu mengadopsi aplikasi EDM dan e-RKAM, baik dalam pengunaan perencanaan anggaran, penganggaran dan pelaporan keuangan dengan berbasis kinerja madrasah . Dengan harapan penggunaan dana BOS lebih efektif dan efisien dalam mendukung percepatan pencapaian Standar Nasional Pendidikan (SNP) berdasarkan hasil Evaluasi Diri Madrasah. Dengan simpulan Madrasah yang terkena sasaran Bimtek dapat menggunakan G-Suite for Education untuk dimanfaatkan dan diterapkan pada penggunaan pengembangan penerapan EDM dan eRKAM tingkat madrasah dengan baik dan kompeten.
\end{abstract}

Kata Kunci : G-Suite for Education's, EDM, e-RKAM

\section{PENDAHULUAN}

Dalam meningkatkan mutu pendidikan, penyelenggaraan pendidikan dituntut untuk lebih mampu mengelola pendidikan dengan pelayanan yang terbaik dalam melayani pendidikan bagi masyarakat. Salah satu aspek penting dalam penyelenggaraan pendidikan adalah aspek pembiyaan. Pembiayaan ini sangat diperlukan dalam penyelenggaraan pendidikan guna memenuhi tuntutan kebutuhan pendidikan. Beberapa hasil studi Bank dunia, menunjukkan bahwa investasi pendidikan sebagai kegiatan inti pengembangan sumber daya manusia terbukti memberikan sumbangan yang sangat signifikan terhadap keuntungan secara ekonomi (Fattah, 2013).

Komitmen pemerintah dalam pembiayaan penyelenggaraan pendidikan dimulai tahun 2005 dengan adanya Progam Operasional Sekolah (BOS) yang dimulai sejak bulan juli 2005 berperan secara signifikan dalam percepatan pencapaian wajar 9 tahun. Tahun 2009 pemerintah melakukan perubahan tujuan pendekatan dan orientasi progam BOS dari perluasan akses menuju peningkatan kualitas progam BOS dan wajib belajar 9 tahun yang bermutu. Mulai tahun 2011 Progam BOS mengalami perubahan dari dana APBN menjadi dana perimbangan yang dilakukan melalui mekanisme tranfer ke daerah dalam bentuk Dana Penyesuaian untuk BOS. Alokasi dana BOS ditetapkan dengan beasaran dana bantuan yang diterima madrasah berdasarkan jumlah siswa masing-masing dikalikan dengan besarnya satuan bantuan. Untuk satuan besaran dana BOS madrasah Tahun 2021 diatur sebagaiman dalam SK Dirjen Pendis 
No.No.6572 Tahun 2020 Tentang Petunjuk Teknis Pengelolaan Bantuan Pendidikan Pada Raudlatul Athfal Dan Bantuan Operasional Sekolah pada Madrasah Tahun Anggaran 2021.

Untuk mewujudkan akuntabiltias penggunaan angaran secara efektif dan efisien dalam pembiayaan pendidikan, Kementerian Agama menggulirkan Proyek Realizing Education's Promise-Madrasah Education Quality Reform (REP-MEQR) IBRD Loan Number: 8992-ID Tahun 2020-2024 bertujuan untuk meningkatkan mutu pengelolaan pendidikan di madrasah dalam binaan Kementerian Agama

Dalam rangka penyempurnaan sistem perencanaan dan pengelolaan anggaran. Kementerian Agama telah mengembangkan platform digital untuk mempermudah madrasah dalam melaksanakan evaluasi diri sebagai dasar penyusunan rencana kerja dan anggaran madrasah. Platform yang selanjutnya disebut e-RKAM atau Rencana Kerja dan Anggaran Madrasah berbasis elektronik dan EDM (Evaluasi Diri Madrasah) diharapkan mampu menjawab tantangan dan kebutuhan madrasah. Aplikasi e-RKAM dan EDM ini merupakan sebuah terobosan penting untuk mendorong tata kelola pendidikan yang efektif dan efisien. Hal ini selaras dengan himbauan Presiden Joko Widodo agar waktu dan energi para kepala madrasah dan guru tidak banyak tersita untuk membuat laporan pertanggung jawaban, namun dapat lebih difokuskan pada pengembangan mutu pembelajaran.

Aplikasi e-RKAM dan EDM membuka peluang pengelolaan dana BOS dan dana lainnya secara lebih transparan dan akuntabel, yang dapat diakses secara berjenjang mulai tingkat madrasah, Kantor Kementerian Agama Kabupaten/Kota, Kanwil Kementerian Agama Provinsi hingga tingkat Kementerian Agama RI. Penggunaan aplikasi e-RKAM dan EDM ini diharapkan dapat memangkas birokrasi pelaporan. Transformasi digital ini merupakan upaya konkrit dalam mewujudkan pengelolaan anggaran pendidikan yang lebih efektif, efisien, transparan, dan bebas korupsi. Menurut Rusman (2012) dan Arifin (2014) perkembangan teknologi informasi yang semakin pesat di era Globalisasi saat ini tidak bisa dihindari lagi pengaruhnya terhadap dunia pendidikan. Tuntutan global menuntut dunia pendidikan untuk selalu senantiasa menyesuaikan perkembangan teknologi terhadap usaha dalam peningkatan mutu pendidikan, terutama penyesuaian teknologi informasi (TIK) bagi dunia pendidika khususnya dalam proses pembelajaran.

Sementara itu Chuang el al (2015) \& Tapscott (2017) menyatakan bahwa teknologi dan internet menawarkan banyak manfaat dalam pengembangan pendidikan dan pembelajaran yang efektif. Produktifitas penggunaan internet dalam pendidikan tercermin pada kenyataan siswa dapat belajar dengan mudah dan mereka bersedia menerima tugas dengan teknologi baru. Internet dalam pendidikan dimanfaatkan dengan tujuan untuk meningkatkan kualitas guru terutama dalam menyediakan sumber daya pengajaran, berbagi ide pendapat, bekerja pada proyek dan memungkinkan adanya kolaborasi guru dan kelompok.

Selain itu (Aryanto,2020), penggunaan internet dalam pendidikan dianggap sebagai suatu proses pengajaran yang efisien dan diikuti presentasi, demontrasi, praktik dan kolaborasi . Hal demikian ini juga diterapkan pada kegiatan Bimtek EDM e-RAKM madrasah sasaran 2020 Proyek Realizing Education's Promise-Madrasah Education Quality Reform (REPMEQR) IBRD Loan Number: 8992-ID tahun 2020-2024 pada Kementerian Agama Kabupaten Semarang.

Untuk mewujudkan pencapaian tersebut, Komponen 1 Proyek ini akan melaksanakan kegiatan Bimbingan Teknis Penerapan Instrumen EDM dan ERKAM secara berjenjang mulai dari tingkat Nasional, Provinsi, Kabupaten/Kota, dan Satuan Pendidikan Madrasah. Serangkaian kegiatan Bimbingan Teknis EDM dan e-RKAM secara berjenjang rencananya akan dilakukan secara face-to-face training mulai dari Tingkat Nasional, Provinsi, Kabupaten/Kota, dan seluruh Satuan Pendidikan Madrasah yang berjumlah 15,422 madrasah pada Tahun 2020, dan sisanya dilaksanakan 2 tahun berikutnya dengan total hampir 50 ribu madrasah. Pelaksanaan Bimtek ini sesungguhnya merupakan sebuah strategi manajemen perubahan yang diperlukan untuk mendukung keberhasilan penerapan sistem perencanaan dan 
penganggaran berbasis kinerja dan sekaligus mendukung keberhasilan program transformasi madrasah digital melalui penerapan e-RKAM.

Namun demikian, sehubungan dengan adanya kondisi kahar (Force Majeure) berupa keadaan darurat nasional Pandemi Covid-19 berdasarkan Keputusan Presiden Republik Indonesia Nomor 12 Tahun 2020 Tentang Penetapan Bencana Nonalam Penyebaran Corona Virus Disease 2019 (COVID-19) sebagai bencana nasional yang tidak memungkinkan dilaksanakannya kegiatan Bimtek secara face-to-face training, sebagai akibat adanya kebijakan physical distancing serta menindaklanjuti hasil rekomendasi dari Rapat Virtual Project Steering Committee (PSC Meeting) tanggal 15 April 2020, sehingga Bimtek Penerapan e-RKAM ini dilakukan dengan menggunakan sistem blended atau hybrid yang menggabungkan sistem syncronous dan asynchronous Oleh karena itu, dalam rangka efektivitas dan kelancaran pelaksanaan kegiatan Bimtek tersebut, diperlukan sebuah Petunjuk Teknis sebagai rujukan penyelenggaraan Bimtek Penerapan Sistem EDM dan e-RKAM secara berjenjang dari pusat, provinsi, kabupaten/kota, sampai dengan tingkat satuan pendidikan madrasah.

Kunci keberhasilan penerapan transformasi digital bukan saja terletak pada kualitas aplikasi, tetapi juga dipengaruhi oleh keberhasilan melakukan change management. Untuk mewujudkan ini merupakan suatu tantangan besar yang memerlukan serangkaian kegiatan seperti sosialisasi, bimbingan teknis, dan pendampingan yang intensif kepada madrasah. Oleh karena itu penulis selaku TIK yang melaksanakan tugas tanggung jawab Bimtek EDM dan eRKAM dengan melakukan penelitian "Best Practice : Implementasi Aplikasi EDM dan eRKAM dengan menggunakan Aplikasi G-Suite Pada Madrasah Sasaran REP-MQER Kabupaten Semarang 2020" guna menuju keberhasilan melakukan change manajement melalui Bimtek sebagai salah satu upaya upaya mitigasi resiko kegagalan transformasi digital EDM dan e-RKAM pada madrasah sasaran.

\section{METODE PELAKSANAAN}

Best Practice ini merupakan deskripsi penelitian hasil tindakan pengawasan melalui bimbingan teknis terhadap madrasah binaan yang menjadi sasaran Bimbingan Teknis penerapan Rencana Kerja Anggaran Madrasah berbasis elektronik (e-RKAM). Proyek Realizing Education's Promise-Madrasah Education Quality Reform (REP-MEQR) IBRD Loan Number: 8992-ID Tahun 2020-2024, bertujuan untuk meningkatkan mutu pengelolaan anggaran pendidikan di madrasah.

Penelitian ini dalah penelitian kualitatif dengan metode deskriptif adalah penelitian yang dilakukan dengan tujuan menggambarkan atau mendiskripsikan implementasi Bimtek EDM dan e-RKAM Proyek Realizing Education's Promise-Madrasah Education Quality Reform (REP-MEQR) IBRD Loan Number: 8992-ID Tahun 2020-2024 berupa pelaksanaan Bimtek yang mencakup pelatihan, ketepatan waktu, suasana, kelengkapan materi, pelayanan /sikap pada kegiatan Bimtek

Metode pelaksanaan kegiatan Bimtek EDM dan e-RKAM adalah dalam bentuk diseminasi Bimbingan Teknis Penggunaan Aplikasi G-Suite for Educatiaon, EDM dan eRKAM untuk dapat diadopsi madrasah sasaran baik penggunaan G-Suite for Educationmaupun kemapuan ketrampilan dalam menjelaskan berbagai menu dalam aplikasi EDM dan e-RKAM kepada Tim Inti Madrasah (TIM) sebagai sasaran Bimtek EDM dan e-RKAM tahun 2020. Dengan demikian perlu adanya studi lapangan sebagai langkah koordinasi dan komunikasi rancangan yang relavan dengan kondisi tempat dilaksanakan Bimtek EDM dan e-RKAM berkaiatan medan tempat dilaksanakan

\section{HASIL DAN PEMBAHASAN}

Bimbingan Teknis EDM dan e-RKAM diawali dengan alur penentuan Sumber daya manusia yang dibutuhkan dalam menfasilitasi pelaksanaan kegiatan EDM dan e-RKAM mulai dari seleksi Tim Inti Nasional (TIN), Tim Inti Propinsi(TIP) Tim Inti Kabupaten (TIK) guna menciptakan sumber daya yang kompeten guna menfasilitasi pelaksanaan pelatihan Bimtek 
EDM dan e-RKAM. Implementasi Bimtek penerapan EDM dan EDM dan e-RKAM didesain dengan pendekatan blended learning, perpaduan antara Bimtek secara daring (dalam jaringan) atau on-line dan tatap muka (syncronous dan asynchronous) diawali dengan pre training platform G-Suite For Education.

Dalam penelitian Best Practice penerapan Aplikasi EDM dan e-RKAM dengan menggunakan Aplikasi G-Suite for Education pada Madrasah Sasaran Kementerian Agama Kabupaten Semarang adalah peneliti sekaligus sebagai koordinator Tim Inti Kabupaten (TIK) Semarang (SK Dirjen Pendis No.4741 Tahun 2020), yang sudah di berikan Bimtek oleh Tim Inti Provinsi (TIP) untuk dapat mengadopsi keunggulan penggunaan G-Suite for Education maupun kemapuan ketrampilan dalam menjelaskan berbagai menu dalam aplikasi EDM dan eRKAM untuk didesiminakan pada Tim Inti Madrasah (TIM) sebagai sasaran Bimtek EDM dan e-RKAM tahun 2020.

Dalam rangka efektifitas keberhasilan pelatihan Bimbingan Teknis penerapan Rencana Kerja Anggaran Madrasah berbasis elektronik (e-RKAM). Proyek Realizing Education's Promise-Madrasah Education Quality Reform (REP-MEQR) IBRD Loan Number: 8992-ID Tahun 2020-2024 pada sasaran madrasah Kementerian Agama kabupaten Semarang dengan tujuan untuk memberikan pengetahuan dan ketrampilan kepada Tim Inti Madrasah sehingga mampu menerapkan EDM dan e-RKAM di Madrasah tempat bertugas

Kedudukan TIK dalam (Petunjuk Teknis Pelaksanaan Bimtek Penerapan EDM dan eRKAM, Madrasah Reform.2020-2024) dalam buku panduan Bimtek berfungsi Fasilitator (sebagai Moderator, Pengajar, Tutor dan Monitoring Evaluasi) dalam penyajian materi ini dituntut untuk lebih responsif terhadap perkembangan berbagai permasalahan yang berkembang pada saat pelatihan baik internal maupun ekternal untuk memastikan setiap target akhir kegiatan tercapai dengan menggunakan latihan https://erkamlatihan.kemenag.go.id EDM dan e-RKAM untuk latihan, sedangkan untuk penerapan https://erkam.kemenag.go.id . Adapun gambaran tentang langkah-langkah hasil pelaksanaan kegiatan sesuai dengan petujuk teknis Bimtek, struktur progam Bimtek, silabus Bimtek sebagai berikut :

\section{A. G-Suite Google For Education.}

Tugas TIK adalah melatih peserta dalam memanfaatkan aplikasi LMS (Learning Manajemen System) berupa G-Suite for educatio shingga setiap peserta TIM terampil menggunakan dalam memanfaatkan, menerapakan pada EDM serta aplikasi e-RKAM bagi setiap peserta Bimtek. Tahapan materi pelaksanaan dengan mengunakan sistem blended atau hybrid yang menggabungkan sistem syncronus asyncronus sebagai berikut:

\section{Email.}

E-mail singkatan dari elektronik-mail yang berarti surat elektronik disingkat Surel, dalam pelatihan ini digunakan untuk aktivasi akun G-Suite for educatian maupun untuk verifikasi, serta pemberitahuan lain-lain ( pemanggilan peserta) baik undangan pelatihan maupun masuk ke google Class Room, masing masing madrasah sudah diberikan akun email kusus (xxx...x.@madrasah kemenag.go.id)

\section{Google Form}

Google form atau Formulir sebagai instrumen evaluasi kegiatan dihubungkan ke spreadsheet. Pengguna dapat melihatnya di halaman "Ringkasan Tanggapan" yang dapat diakses dari menu Tanggapan.

\section{Google Classroom}

Pada kegiatan ini google classroom sebagai tempat penyimpanan materi-materi yang telah di buat sebelumnya.

\section{Google Drive}

1) Alasan menggunakan G-Suite Google for education menjadi solusi kelas virtual.

a. Google Drive.

- Kapasitas penyimpanan Unlimited.

- Keamanan penyimpanan (jika mengirim file/folder diluar domain yang sama dengan anda, maka akan diinformasikan oleh sistem) 
- Dapat membuat Share Drive dan dibagikan pada rekan untuk kerjasama

b. Google Meet.

- Tanpa batas penggunaan waktunya, sehingga dapat digunakan secara maksimal untuk Bimtek.

- Dapat mengaktifkan fungsi stream.

- Fungsi Meet dapat dimaksimalkan dengan original Meet, Google Calender dan Google Classroom.

- Proteksi dengan admin console.

- Didukung dengan berbagai extension yang disesuaikan dengan kebutuhan.

c. Google Classroom

- Maksimal 20 Guru dalam satu kelas Classroom

- Maksimal 1000 siswa dalam satu kelas.

- Guru dapat membuat kelas tanpa batas.

- Dapat mengundang siswa classroom tanpa batas.

- Guru dapat mengundang wali murid dengan fitur Guardian.

- Guru dapat mengundang maksimal 20 email guardian pada masing-masing siswa.

- Google Meet terintregrasi dengan setiap kelas Classroom.

- Keamanan Classroom dapat dikelola dengan sistem admin console masing-masing domain.
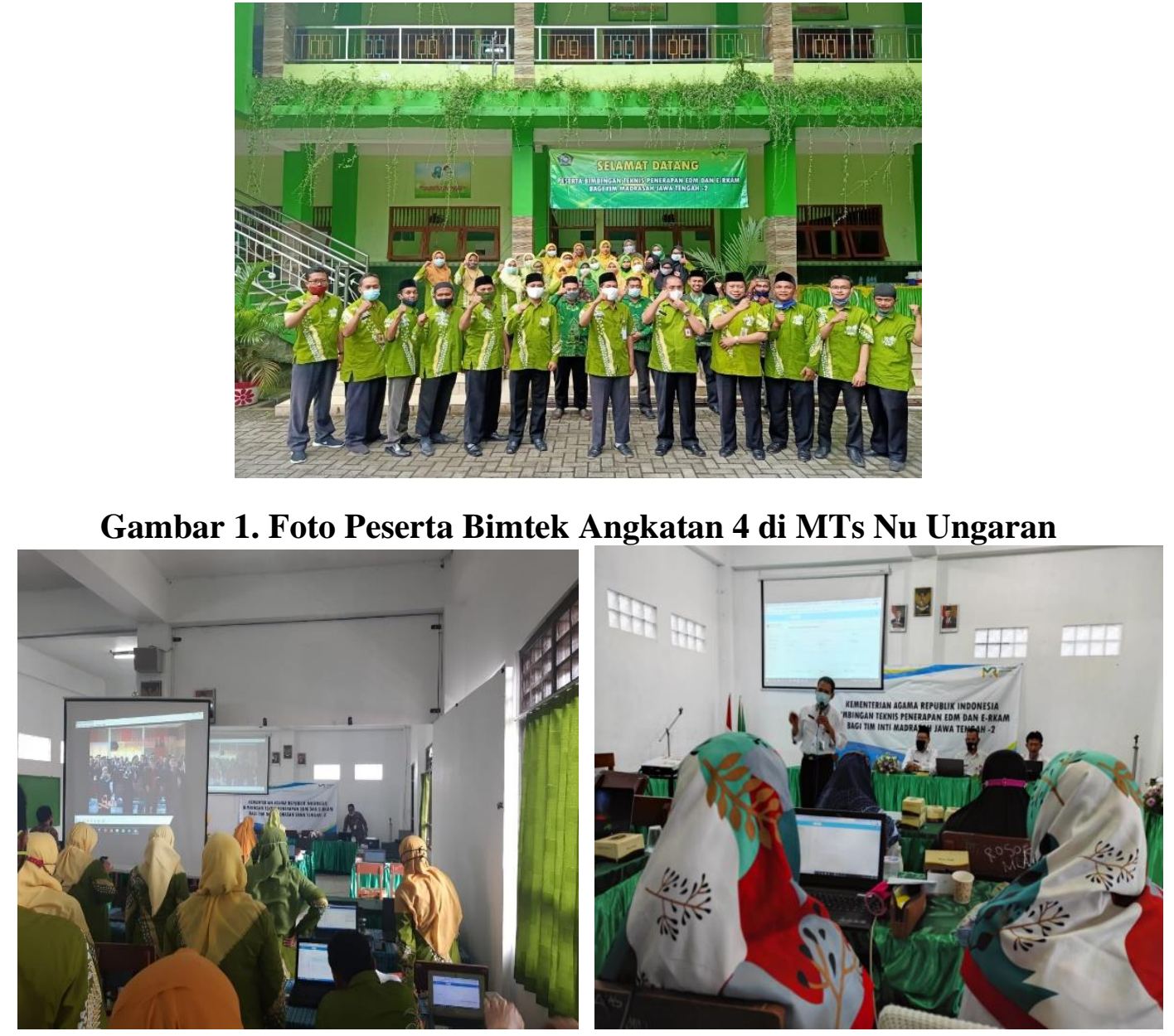

Gambar 2. Penyajian Materi EDM\& e-RKAM

\section{A. Masalah Yang Dihadapi}

Selama kegiatan berlangsung sangat antusias, hal in terlihat konsistensi peserta mengikui kegiatan Bimtek selama selama 5 hari. Pelatihan/Bimtek merupakan kegiatan 
pelatihan dan pengembangan serta kemampuan yang dapat digunakan untuk memecahkan masalah yang dihadapi setiap individu peserta, sedangkan efektifitas keberhasilan secara umum menunjukkan sejauh mana pencapaian tujuan yang telah ditentukan.Efektifitas diukur dari beberapa jumlah siswa yang berhasil mencapai tujuan belajar dalam waktu yang telah ditentukan (Mudhafier,1987). Hal ini dikuatkan oleh Mangkin (2018) yang menyatakan bimtek efektif akan mewujudkan bimtek yang berjalan Optimal serta beberapa materi dapat dipahami oleh peserta Bimtek. Akan tetapi ada beberapa hal yang menjadi kendala dalam pelaksanan Kegiatan Bimtek ini :

a. Masalah yang dihadapi dalam pelaksanaan Bimtek ini adalah peserta belum terbiasa dengan aplikasi G-Suite for education's, EDM dan e-RKAM dan merupakan hal baru bagi peserta. Apalagi dengan menggunakan kelas virtual Google Clasroom secara syncronus a syncronus.

b. Izin penyelengaraan Bimtek dari dari Gugus Covid-19 Kabupaten.

c. Masalah yang dihadapi kendala pemadaman listrik yang dikarenakan pelaksanaan bimtek ini bertepatan dengan musim hujan.

d. Lemahnya sinyal dalam akses e-RKAM

e. Gangguan suara hujan dan petir

\section{B. Cara Mengatasi Masalah}

1. Pembimbingan individu dan pendampingan agar aplikasi betulbetul semua sudah terverifikasi secara benar adalam aktivasi progam dan pendampingan mentoring tutor sebaya sesama TIM.

2. Perubahan jadwal kegiatan

3. Dalam antispasi listrik dengan menaikkan kapasitas listrik, serta persiapan genset, hal ini dikarenakan pelaksanaan pada musim hujan sehingga rawan pemadaman listrik .

4. Menggunakan sinyal terkuat yang ada diwilayah tersebut yang pada waktu pelaksaan di hari pertama sudah teruji kekuatan sinyalnya dan diharapkan tidak menggunakan tathering sinyal ke peserta lain.

5. Untuk mengatasi gangguan suara hujan dan terutama suara petir dimohon seluruh peserta membawa headset agar lebih terfokus pada materi pelatihan.

\section{KESIMPULAN}

Pelaksanaan Bintek Implementasi Aplikasi EDM dan e-RKAM dengan menggunakan Aplikasi G-Suite for Educationpada Madrasah Sasaran REPMQR Kabupaten Semarang 2020, setelah melalui pembimbingan Bimtek EDM dan e-RKAM kerjasama TIP, TIK dan TIM didapatkan sebagai suatu bentuk kegiatan penting dengan fokus Proyek Realizing Education's Promise-Madrasah Education Quality Reform (REP-MEQR) IBRD Loan Number: 8992-ID Tahun 2020-2024 sebagai implementasi penerapan Sistem e-RKAM ( Rencana Kerja dan Anggaran Madrasah Berbasis elektronik) . Dilatarbelakangi oleh kenyataan belanja anggaran di Kemenag belum sepenuhnya efisien, dengan terbatasnya data penggunaan BOS, minimnya monitoring serta informasi capaian Standar Nasional Pendidikan maka diperlukan penerapan Sistem e-RKAM yang memungkinkan terjadinya efisiensi pembelanjaan melalui sistem perencanaan dan penganggaran berbasis kinerja madrasah penerima BOS lebih efektif dalam mendukung percepatan pencapaian Standar Nasional Pendidikan (SNP) berdasarkan hasil Evaluasi Diri Madrasah (EDM).

Berdasarkan hasil pelaksanaan kegaiatan dapat disimpulkan bahwa kegiatan Bintek Implementasi Aplikasi EDM dan e-RKAM dengan menggunakan Aplikasi G-Suite for Educationpada Madrasah Sasaran REP-MQR Kabupaten Semarang 2020, dapat dilaksanakan dengan baik melalui tugas TIK dalam melatih dan membimbing peserta guna memanfaatkan aplikasi LMS (Learning Manajemen System) berupa G-Suite for Educationdengan Google Classroom melalui tahapan materi pelaksanaan mengunakan sistem blended atau hybrid yang menggabung- kan sistem syncronus asyncronus dengan hasil akhir yang dicapai baik secara 
kuantitatif maupun kualitatif dapat dijelaskan sebagai ukuran keberhasilan Bimtek (a) Tingkat efektifitas pelaksanaan Bimtek sangat tinggi terbukti setiap peserta TIM terampil menggunakan berupa $G$-Suite for Education dalam memanfaatkan, menerapakan pada aplikasi EDM serta aplikasi e-RKAM sesusai tugas fungsi akun peserta Bimtek masing-masing (b) Kompetensi Tim Inti Kabupaten (TIK) dalam menfasilitasi pelaksanaan pelatihan Bimtek EDM dan eRKAM dapat berjalan secara optimal dengan tujuan menciptakan sumber daya Tim Inti Madrasah yang kompeten dalam penerapan EDM dan e-RKAM sesuai skenario dan tahapan, langkah-langkah penerapan materi Bimtek bagi peserta dalam menjalankan tugas sesuai tugas fungsi akunnya. (c) Peserta pelatihan Bimtek TIM telah mampu mengembangkan pengetahuan dengan analisis hasil EDM dalam menyusun rencana anggaran, penganggaran, dan laporan kegiatan anggaran terbukti dengan hasil penyerapan anggaran bos madrasah tahap 1 tahun 2021 dengan tingkat realisasi anggaran $100 \%$.

\section{DAFTAR PUSTAKA}

Arifin, Z. (2014). Evaluasi pembelajaran, prinsip, teknik dan prosedur. Bandung : Remaja Rosdakarya.

Aryanta, I.K.D. (2020). Implementasi aplikassi UKBM berorientasi STEM Untuk Meningkatkan hasil belajar Fisika siswa. Indonesian Journal of Educational Development, 1(3).357-365.

Chuang,S, Lin,F.\& Tsai,C. (2015). An exploration of the relationship between Internet selfefficacy and sources of Internet self-efficacy among Taiwanese university student. Computer in Human Behavior, 48(3),147-155.

Dirjen Pendis No. 4741. (2020). Penetapan TIM Inti Kabupaten/Kota Bimbingan Teknis (Bimtek) Penerpan Sistem Rencana Kerja Anggaran Madrasah Berbasis elektronik ( e-RKAM). No. 4741: Kemenag.

Dirjen Pendis. (2020). Tentang Petunjuk Tenis Pengelolaan Bantuan Pendidikan Pada Raudlatut Athfal Dan Bantuan Operasional Sekolah pada Madrasah Tahun Anggraran 2021. No.6572: Kemenag.

Dirjen Pendis.2020. Petunjuk Teknis Pelaksanaan Bimbingan Teknis Penerapan EDM dan eRKAM”. kemenag. https://mrc. kemenag.go.id

Madrasahreform. (2020). Proyek Realizing Education's Promise-Madrasah Education Quality Reform (REP-MEQR) IBRD Loan Number: 8992-ID. Kemenag.

Mangkin, B. R. (2018). Analisis Efektifitas Pelaksanaan Program Bimtek Usaha Mikro Kecil Menengah, Universitas Sanata Dharma.

Mubah, A Safaril. (2011). "Strategi meningkatkan daya tahan budaya lokal dalam menghadapi arus globalisasi”. Departemen Hubungan Internasional, FISIP, Universitas Airlangga

Mudhafier. (1987). Dasar-dasar Evaluasi Pendidikan. Jakarta: Remaja Karya

Nanang, Fattah. (2013). Ekonomi dan Pembiayaan Pendidikan. Bandung: Remaja Rosda Karya.

Pendis. (2020). Basic Training Google for Education fasilitator TIK Batch 30 . Kemenag : www.dugi.com

Rusman. (2012). Pembelajaran berbasis teknologi informasi dan komunikasi. Jakarta. Raja Grafindo Persada

Pikiran Rakyat. (2021). Kemenag terbaik dalam pencairan dana BOS Madrasah

Tahun2021,Banyumas.https://lensabanyumas.pikiran-rakyat.com/nasional/pr-242345280/20kantor-kemenag-terbaik-dalam-pencairan-dana-bos-madrasah-2021-selamat

Tapscott, D. (2017). The digital economy, promise and peril in the age of networked intelegence . Mc Graw-Hill. 